Article

\title{
Reformation Leads to Self-Reliance: The Protestantism of Transcendentalism
}

\author{
Rachel B. Griffis \\ Department of Language and Literature, Sterling College, 125 W Cooper Ave, Sterling, KS 67579, USA; \\ rachel.griffis@sterling.edu; Tel.: +1-620-278-4326 \\ Academic Editor: Christopher Metress \\ Received: 27 December 2016; Accepted: 14 February 2017; Published: 21 February 2017
}

\begin{abstract}
This article examines connections between the Protestant Reformation and American literature and argues that Protestantism's best expression exists in contemporary iterations of self-reliance. The first part focuses on William Ellery Channing's and Ralph Waldo Emerson's literary criticism of John Milton, a poet who represents the Protestant ideals these writers combine with American principles to develop the literary tradition. The second part discusses the trajectory of American literature in the nineteenth century and extends this discussion to current assumptions regarding teaching and learning.
\end{abstract}

Keywords: Protestantism; transcendentalism; self-reliance; Milton; Channing; Emerson

In 1775 when the British conservative Edmund Burke commented on revolutionary and religious zeal in America, he drew attention to the unique relationship between the Protestant Reformation and the identity of America, the site for what he called "the protestantism of the Protestant religion" ([1], p. 71). When the American transcendentalist literary movement emerged in the next century, the writers of this period also drew upon the Protestant Reformation to express the tenets of their own age. American literary critic and Catholic convert Orestes Brownson's aptly titled article "Protestantism ends in Transcendentalism" (1846) describes transcendentalism as "nothing but the fundamental principle of the Protestant reformation itself" ([2], p. 115). Similarly, Ralph Waldo Emerson, the quintessential transcendentalist, suggests the Protestant Reformation produced Calvinism, which "rushes to be Unitarianism, as Unitarianism rushes to be pure Theism" ([3], p. 117). Like Burke, Brownson and Emerson locate America as a place where the Reformation manifested itself, although they point to the movements of the nineteenth century, and not the founding of the country, as the furthest reaches of Protestant thought.

Historians, theologians, and literary scholars have long noted the complementary relationship between Protestantism and nineteenth century print culture in America. However, scholars have tended to discuss this relationship in terms of the eventual secularization of American culture rather than to consider literature as a significant medium for the continuation and development of American Protestantism, which may be most visible today in the cultural virtues of self-reliance. ${ }^{1}$ This article will demonstrate the importance of teaching nineteenth American literature as a powerful agent for Protestantism as well as connect this century's literary and religious developments to current assumptions about learning and education. In the first part, I will suggest that the role many

1 For example, Brad S. Gregory, whom I will reference in the body of the article, connects Protestantism to secularization when he argues that "the expansion of rights inaugurated by the right to religious liberty would eventually include the right to religious unbelief and the right to live in ways antithetical to Christian morality" ([4], p. 188). While I agree with Gregory that Protestantism set in motion the option of unbelief, my article focuses on the ways in which the culture of self-reliance, wrought from individual rights, is itself an expression of Protestantism and evidence of religiosity in America. 
writers, specifically William Ellery Channing and Ralph Waldo Emerson, expected literature to play in American life is indicative of Protestantism's legacy in the United States. By examining Channing's and Emerson's criticism on John Milton, this section will highlight how they idealized literature as the conduit for the values and concepts of individualism, freedom, and self-government. The second part traces the role of literature in the moral lives of Americans through trends in the latter half of the nineteenth century and concludes with a discussion of education in light of the Reformation through an aspect of Protestantism that inspired many American writers: what Brownson describes as "the right of private judgment" ([2], p. 125). ${ }^{2}$ Overall, I hope to show that the development of the American literary tradition reflects the far-reaching effects of the sixteenth century European Reformation, which distantly yet significantly inspired the literature of the United States to function as a moral voice in the lives of the people.

\section{Protestantism Gives Way to Transcendentalism: Milton, Channing, and Emerson}

In the first few decades of the nineteenth century, American writers became increasingly concerned with developing a literary tradition that was uniquely American and equal to England's. In 1815, Walter Channing lamented the absence of "a literature of our own" as he speculates whether,

our venerable fathers, when they deserted their own country, bring with them a thread of that literary tissue, so varied, so rich, and so beautiful, which had been the result of the dignified and delightful labour of England through so many ages of its history? Have we, their descendants, united our industry to theirs? ([5], pp. 35-36)

Channing's desire for a specifically "American" literature demonstrates his concern that the nation's writers produce works exemplifying the lives and values of American people in a way that equals, if not rivals, creative works by the British. In 1820, the British writer Sydney Smith fanned the fires when he taunted Americans regarding their literature. "In the four quarters of the globe," he writes, "who reads an American book? Or goes to an American play? Or looks at an American picture or statue?" ([6], p. 79). The nation's writers in the first half of the nineteenth century responded to remarks such as Channing's and Smith's by building a national literature, of which the transcendentalists were a vital part.

The transcendentalists' vision for a national literature was inspired by their moral, Protestant-inflected ideals as much as their patriotism, an important point for teachers and students of the Reformation and the American literary tradition. F.O. Matthiessen acknowledges the moral undertones of this literary movement when he writes, "the transcendent theory of art is a theory of knowledge and religion as well" ([7], p. 31). More pointedly, Perry Miller asserts "that the Transcendental movement is most accurately to be defined as a religious demonstration," and, "Neither Emerson nor Thoreau conceived of himself as an artist, but each of them came close-perilously close perhaps-to imagining himself a prophet" ([8], pp. 8-9). As Matthiessen's and Miller's comments show, many of the transcendentalists studied today by undergraduates and included in anthologies believed their objectives were religious ones and that they furthered the efforts of the sixteenth century reformers. For example, Margaret Fuller, hoping to renew what she calls the Protestants' "great principle," writes to support what she understands as the reformers' original mission: "respect for the right of private judgment and the decision of conscience in the individual" ([9], p. 93). The novelist Catharine Maria Sedgwick celebrates "the great principle achieved and fixed by the Protestant battle- the right of private judgment" as she berates the Calvinists for obstructing this principle ([10],

2 Many other nineteenth century authors used this phrase to refer to the accomplishments of the Protestant Reformation, including Catharine Maria Sedgwick and Margaret Fuller, who will be cited in this article. 
p. 338). ${ }^{3}$ The Unitarian minister William Ellery Channing, the older brother of Walter, calls for the continuation of the Reformation in his promotion of Unitarianism because "a Papal dominion is perpetuated in the Protestant church" ([12], p. 101). These statements, which express the common goals of the European reformers and the transcendentalists, demonstrate how many American writers in the nineteenth century viewed themselves as stewards of Protestantism in the New World and not necessarily apostates who sought to liberate others from religion. They were instead seeking the fulfillment of freedom promised by the Reformation. ${ }^{4}$

Emerson, perhaps the most studied and influential of the transcendentalists, writes about movements such as the Protestant Reformation and the American Revolution as steps in the path to self-reliance, the ultimate form of human freedom. He suggests that Protestantism progresses into such movements as "Calvinism into Old and New schools; Quakerism into Old and New," as a result of one "key" phenomenon: "the mind had become aware of itself" ([3], pp. 325-26). Emerson goes on to describe and celebrate the progress of human culture toward his self-reliant ideals:

\begin{abstract}
Men grew reflective and intellectual. There was a new consciousness. The former generations acted under the belief that a shining social prosperity was the beatitude of man, and sacrificed uniformly the citizen to the State. The modern mind believed that the nation existed for the individual, for the guardianship and education of every man. This idea, roughly written in revolutions and national movements, in the mind of the philosopher had far more precision; the individual is the world. ([3], p. 326)
\end{abstract}

The sixteenth century European Reformers and the eighteenth century American Revolutionaries, Emerson suggests, had conceived of new religions and nations while unwittingly grasping at the realization of the individual, to which the transcendentalists gave release with works like "Self-Reliance" (1841) and Walden (1854). In answering the call for a national literary tradition and furthering the work of the Protestant Reformation, Emerson argues that both government and religion should serve the individual, whom he proclaims, "is the world" ([3], p. 326). Or, as Henry David Thoreau states, "Now that the republic — the res-publica-has been settled, it is time to look after the res-privata-the private state" ([14], p. 174). The Protestant Reformation and the founding of the United States were, in the transcendentalists' view, events that would culminate in their own movement. As Thoreau writes, they then turned to "the private state" to advance inner freedom, as they believed Americans needed to be liberated from tradition and authority, and that literature was a particularly well-suited medium for their message of freedom ([14], p. 174). ${ }^{5}$

Emerson and Channing both produced essays in the 1820s and 1830s that reveal the influence of Protestantism in the American literary tradition, and these works help students to understand better the ideas expressed in more familiar transcendentalist texts such as "Self-Reliance" and Walden. In his "Remarks on National Literature" (1830), Channing conveys aspirations for a literature that accomplishes work nearly indistinguishable from that of religion and the clergy. He hopes literature can "produc[e] superior men," and he states, "We want a literature, in which genius will pay supreme, if not undivided homage, to truth and virtue" and which "will give place to a wise moral judgment; which will breathe reverence for the mind, and elevating thoughts of God" ([12], pp. 168, 185). Moreover, Channing's vision that the nation's literature "will pay supreme, if not undivided" attention

3 Catharine Maria Sedgwick also positively refers to Burke's description of religion in America in The Linwoods (1835), a reference that indicates American writers' interest in promoting the principles of Protestantism in literature and culture ([11], p. 41).

4 Alexis de Tocqueville, a French writer who visited America in the 1830s, affirms how the Americans understand their Protestant heritage. He writes that Americans, "after having shaken off the authority of the pope, acknowledged no other religious supremacy: they brought with them into the New World a form of Christianity, which I cannot better describe, than by styling it a democratic and republican religion" ([13], p. 245).

5 It is important to note that the transcendentalists' preoccupation with freedom did not exclude the question of slavery, though they held that inner liberty was the highest form of freedom. They were indeed aware of the contradictions in American thought that allowed the Declaration of Independence and the institution of slavery to co-exist. 
to a morality that results in "reverence for the mind" along with "elevating thoughts of God" reveals the particularly Protestant declensions of religion in nineteenth century America, which focused on elevating both humanity and God ([12], p. 185). Channing's and Emerson's literary criticism also provides further insights into the transcendentalists' expectations for literature. Their admiration for John Milton, the British, Puritan poet of Paradise Lost (1667), specifically expresses how they envision a literature that celebrates their Protestant ideals and values, including individualism, freedom, self-government, and the elevation of humanity. ${ }^{6}$ As Brad S. Gregory explains, Milton is a "radical Protestant" who "simply spelled out what was implicit in Luther, Calvin, and every other sixteenth-century Protestant reformer," an explanation that sheds light on the transcendentalists' regard for this poet and their decision to draw upon him as they created their literary movement ([4], p. 215).

Respectively written in 1826 and 1838, Channing's and Emerson's essays on Milton depict the poet as a progressive Protestant with ideas that anticipate and resemble the transcendentalists' views in nineteenth century America. Channing's essay on Milton emphasizes the poet's commitment to freedom by highlighting the ways in which the poet interacts with civic and religious issues, a commitment he argues is motivated by Milton's elevation of freedom of the mind. Channing states,

Freedom, in all its forms, and branches, was dear to him, but especially freedom of thought and speech, of conscience and worship, freedom to seek, profess, and propagate truth [...] The tyranny which he hated most was that which broke the intellectual and moral power of the community. The worst feature of the institutions which he assailed was, that they fettered the mind. ([16], p. 508)

Writing against the institutional "fetter[ing] of the mind," and the inhibition of people's "moral" and "intellectual" "power[s]," Channing emphasizes the incorporeal aspects of freedom with his references to "thought" and "conscience" ([16], p. 508). Like Channing, Emerson considers Milton "an apostle of freedom," especially highlighting him as an individualist ([17], p. 271). For example, writes Emerson, "he is never lost in a party. His private opinions and conscience always distinguish him" ([17], p. 270). Emerson also praises Milton's rejection of spiritual authority by his absence from church, noting, "The most devout man of his time, he frequented no church" ([17], p. 273). Emerson admires Milton for his spiritual autonomy, for the independence of heart and mind to eschew church authority and to take responsibility for his own spirituality, tendencies Emerson himself also possessed. ${ }^{7}$

Milton's role as "an apostle of freedom" also gives both Emerson and Channing a way to express their high view of human nature, a view they believed had its roots in the Protestant cause, but had been obstructed by Calvinism in America ([17], p. 271). For example, as he writes about Milton's elevation of humanity, Channing suggests that Milton's contribution to theology is an emphasis on the human aspects of God. He argues that Milton "is more disposed than Christians in general to conceive of the Supreme Being under the forms and affections of human nature," adding, "He thought, not so much what man is, as of what he might become" ([16], pp. 511, 509). Emerson, similarly, counts among Milton's great achievements his resolve "to raise the idea of Man in the minds of his contemporaries and of posterity" ([17], p. 254). Taking his characteristic shots at Calvinism, Emerson also praises Milton for Paradise Lost, a work he interprets as glorifying the first man. Writing unabashedly about the glories of this first man, Emerson suggests, allows the poet to "reascend to the height from which

6 Milton was very popular among Americans in both the eighteenth and nineteenth century. Twenty-eight editions of Milton's poetry were published by American printers between 1787 and 1815 (Sensabaugh [15], p. 17).

7 The Milton presented in this article is as Channing and Emerson interpret him, and I am interested in that interpretation for what it reveals about Channing and Emerson. Many Miltonists indeed read the poet as more Puritan than transcendentalist. For example, regarding Paradise Lost, Stanley Fish has argued in Surprised by Sin that Milton tricks the reader into indulging his or her disorderly sympathies, wherein "he places himself in a compromising situation," which is that "He has taken his eyes from its proper object—-the glory of God and the state of his own soul" ([18], p. 12). In doing so, Milton reinforces the concept of original sin, a concept which Channing and Emerson found repugnant and wanted to minimize in their reading of Milton. 
our nature is supposed to have descended," a position the transcendentalists believed Americans encumbered with Calvinism had forgotten or perhaps deliberately ignored ([17], p. 274). ${ }^{8}$

Channing's and Emerson's aspirations for American literature in their essays point to the Protestant roots of their ideas and how morality was promoted through literature in the nineteenth century. Furthermore, connecting the Reformation and transcendentalism shows that the Protestants' contentions and causes, such as their distrust of authority and their elevation of the individual, lead to the kind of thinking eventually articulated by Emerson. Like Milton, Emerson expresses such radically Protestant sentiments in "Self-Reliance" as "To believe your own thought, to believe that what is true for you in your private heart is true for all men,-that is genius" ([19], p. 29). In agreement with Burke's and Brownson's statements which began this article, Gregory's theological genealogy suggests that the United States was the place where "formally [ ... ] individuals, their rights secured by the state, would choose their own goods as they chose their own beliefs" ([4], p. 217). This assertion effectively articulates in political terms what Emerson claims for the inner lives of individual Americans. Joe B. Fulton more directly establishes a lineage between the reformers and transcendentalists when he writes that "New England's new theological and literary movement [was] the logical outcome of Luther nailing his ninety-five theses to the church door in Wittenberg and Calvin penning his Institutes while exiled in Switzerland" ([20], pp. 404-5). These genealogies point to the possibility that literature was not only the medium through which Americans received the cultural virtues of self-reliance, but also the most effective conduit for the growth of Protestantism, from which self-reliance originates.

\section{American Literature's Moral Purpose: Individual Interpretation and Learning}

Protestantism continued to influence American literature in the movements that followed transcendentalism, a lineage particularly evident in the ways literature participated in the moral lives of Americans during and after the Civil War. In his call for a national literary tradition, Channing states that poetry takes on salvific proportions, a role that will become more evident as the nineteenth century progresses. Poetry, Channing writes, "the divinest of all arts," "has the same tendency and aim with Christianity: that is, to spiritualize our nature" ([16], p. 498). Miller explains such statements as a result of the "precommitment" of the transcendentalists "to making literature a substitute for religion" ([8], p. 14). One of the results of poetry having "the same tendency and aim with Christianity," as Channing puts it, is that literature becomes a source for moral questions and answers and the nation's writers become the clergy ([16], p. 498). For example, a character in one of William Dean Howells's novels, The Rise of Silas Lapham (1884-1885), asks a minister at a dinner party if he is "envious" of the power of novels in people's lives ([21], p. 175). Similarly, in one of Mark Twain's sketches, he writes,

nine-tenths of all kindness and forbearance and Christian charity and generosity in the hearts of the American people to-day, got there by being filtered down from their fountain-head, the gospel of Christ, through dramas and tragedies and comedies on the stage, and through the despised novel [ ... ] and NOT from the drowsy pulpit! ([22], p. 53)

These developments in American literature point to the deepening moral imperatives of the nation's writers in the nineteenth century and the waning authority of the very sources of oppression Emerson had warned his readers about, such as the church and tradition. In my classroom, I ask my students to identify Protestant and Emersonian sentiments in works from and after the Civil War period not only to help them make connections between sixteenth century Europe and American literature but also to encourage them eventually to recognize the prevalence of Emersonian Protestantism in contemporary culture.

8 Given Milton's association with Calvinism, a branch of Christianity the transcendentalists eschewed, Emerson and Channing thus worked to curtail this tradition's impact on Milton's thinking. Channing, for example, writes, "Swayed as Milton was by the age in which he lived, his spirit could not be subdued to the heart-withering faith of the Genevan school" ([16], p. 517). 
Other historical and cultural phenomena in the nineteenth century contributed to the elevation of literature in the moral lives of Americans, and several are useful for helping students to trace the links between the Reformation and American literature and culture. Two are worth mentioning here for their relationship to reading and learning: Protestant print culture and skepticism regarding the authority of the Bible. Protestant print culture, with its emphasis on individual Bible reading and the narrative testimonies of believers, promoted the dissemination of morals through literary texts. David S. Reynolds suggests that clergy adapted their work according to the literary market, "knowing they had to compete with novels for the public's attention," thus creating their own publications ([23], p. 15). In The Word in the World (2004), Candy Gunther Brown studies evangelical print culture specifically, showing how literature was a fundamental aspect of this branch of Protestantism. Although many of the writers Brown highlights would not endorse the cynical attitudes of Howells and Twain regarding the role of clergy and sermons in the Christian life, her research nevertheless shows that literature was essential to the success of evangelicalism. She explains, "Readers and writers made progress in a spiritual journey through textual practices, giving and receiving encouragement from other readers and writers, by placing themselves within the story of the church's communal pilgrimage" ([24], p. 11). Although these evangelical communities did not follow, at least directly, Emerson's enjoinder, "Nothing can bring you peace but yourself," they expressed self-reliant ideals in their high view of literature's ability to augment the individual's moral life ([19], p. 52). They also had similar, non-aesthetic goals. As Brown asserts, "Usefulness, rather than genre or form, was the primary characteristic that marked texts as evangelical" ([24], p. 7). Moreover, as Channing's and Emerson's criticism of Milton indicates, evangelical print culture was preoccupied with conveying certain ideas rather than developing pristine literary forms. ${ }^{9}$

Additionally, the authority of the Bible strenuously came under question during the Civil War, a conflict this holy book failed to solve. Mark A. Noll argues that this conflict "revealed a significant theological crisis," which perhaps suggests how and why, for many Americans, literature replaced the sermon as the conduit for morals ([27], p. 6). Harriet Beecher Stowe's Uncle Tom's Cabin (1854), for example, depicts the opposing views of Bible-readers in relation to slavery while employing the sentimental formula to show her readers which interpretation is most moral. Furthermore, in her concluding remarks, she describes the Protestant, self-reliant way an American can grow in morality and thus function as a responsible and compassionate member of a community. She famously states, "every individual can judge," and "they can see to it that they feel right" ([28], p. 624). Stowe's vision for advancing a moral view of slavery and human rights assumes, as Gregory points out, that people "would choose their own goods as they chose their own beliefs," and so she undertook a persuasive writing project that would convict individuals through their feelings to support the abolition of slavery ([4], p. 217). Outsold only by the Bible in the nineteenth century, Uncle Tom's Cabin reveals, perhaps unwittingly, that Scripture was not reliable for answering the slavery question. Instead, this novel suggests that individual sentiments, albeit Christian inflected ones, would restore order and morality in the country, a suggestion that points to the effects of the Protestant Reformation on the development of American literature. As Gregory suggests,

From the outset of the Reformation to the present day, the insistence on sola scriptura and its adjuncts has produced and continues to yield an open-ended range of incompatible interpretations of the Bible, with centrifugal social and wide-ranging substantive implications for morality. ([4], p. 205)

9 As Anne C. Rose points out, "the Transcendentalists began their careers as reformers of religious philosophy," and as a result, the literature tends to have a moral purpose over an aesthetic one ([25], p. 39). A focus on content over form is a characteristic of the transcendentalists, and this focus is evident in their criticism of Milton, which emphasizes "the ethical and didactic excellences in Milton" while overlooking "a technical examination of the stylistic features" (Pettigrew [26], p. 58). 
The American literary tradition, though making no claims to function as the sacred word of God, encourages the self-reliant protesters and descendants from the sixteenth century to interrogate texts, to arrive at their own interpretations and thus their own beliefs.

Gregory's observation regarding the "adjuncts" of "sola scriptura" is evident in Emerson's statement at the outset of "Self-Reliance" quoted above: "To believe your own thought, to believe that what is true for you in your private heart is true for all men,--that is genius" (Gregory [4], p. 205; Emerson [19], p. 29). The elevation of believing for oneself and thinking for oneself are concepts to which the Reformation gave rise, concepts which Emerson expressed explicitly, and which American education often takes for granted. It is cliché among educators to state that one's goals for a particular course are for students "to think for themselves," as such goals are assumed. In Why Read? (2004), Professor Mark Edmundson expresses the heritage of Emersonian self-reliance in the academy when he argues that students must decide for themselves which goods they will pursue on their intellectual journeys "through encounters of the best that has been known and thought" ([29], p. 86). He continues,

We all have promise in us; it is up to education to reveal that promise, and to help it unfold. The power that is in you, says Emerson, is new in nature. And the best way to release that power is to let students confront viable versions of experience and take their choices. ([29], p. 86)

David Foster Wallace also articulates these educational principles in his famous commencement address when he asserts, "Learning how to think' really means learning how to exercise some control over how and what you think" ([30], p. 53). Edmundson's and Wallace's lofty expressions are what Brownson describes pejoratively as the natural consequences of "the right of private judgment," though Edmundson's vision in which students seriously consider "the best that has been known and thought" and "take their choices" is entirely sincere (Brownson [2], p. 125; Edmundson [29], p. 86).

On the other hand, what Brownson perhaps anticipates in his critique of Protestantism and transcendentalism is that American students will resist learning because of the Emersonian platitudes they have internalized, often without having read Emerson himself. Emerson's statements_-"imitation is suicide," "Trust thyself," and "Whoso would be a man must be a nonconformist" —inform many students' perspectives on education ([19], pp. 29-31). Or, they echo Thoreau, who criticizes formal schooling and suggests that students "should not play life, or study it merely, while the community supports them at this expensive game, but earnestly live it from beginning to end" ([31], p. 38). As Edmundson concedes, students often protect themselves from learning that requires them to "reveal and risk [themselves]," only tolerating the kind of knowledge that "allow[s] [them] to keep [their] cool" ([29], p. 13). They choose the least demanding goods which require minimal change and growth. Alluding to the transcendentalists' ideals, R.R. Reno explains Edmundson's concession by drawing attention to the shortcomings of current and prevalent American assumptions about education. For Reno, learners lack a disposition of "docility," or, "the capacity to be guided or led" ([32], p. 98). More pointedly, he states,

neither students nor teachers are disposed to accept the instruction of the wise, whose voices continue to live in the great books of the past. We will not allow ourselves to be taught about spiritual, moral, and political realities. We are indocile to tradition. ([32], p. 100)

Reno's observation that students and teachers alike are "indocile to tradition" recalls the individualism of the transcendentalists, which they inherited from the Protestants who empowered the individual with the right of private judgment. This indocility is why Brownson, according to Carl F. Krummel, believed that Catholicism would "[balance] the democratic tendency with respect for authority" ([33], p. 24). 
Gregory's account of the Protestant perspective on authority, specifically that "in the end one was one's own sovereign authority, answerable only to God," is also an apt description of the transcendentalists' views which persist in the "indocility" that has become commonplace in contemporary American culture ([4], p. 215). In Brownson's words, "Protestantism, then, necessarily lays down the principle, that each and every man is in himself the exact measure of truth and goodness, - the very fundamental proposition of transcendentalism" ([2], p. 127). Gregory argues that this high view of the individual and the subsequent impoverished view of authority "undermined the importance of counsel that shaped one's moral formation in a moral community" ([4], p. 215). Its current impact on educational communities is that the virtue of docility, as Reno notes, is neither practiced nor recognized. The great literary critic R.W.B. Lewis also makes the connection between transcendentalism and extreme individualism when he aptly suggests, in The American Adam (1955) that "The dismissal of the past has been only too effective: America, since the age of Emerson, has been persistently a one-generation culture" ([34], p. 9).

Teaching students who have internalized Emerson thus presents its own challenges, as few of us have the audacity of Stanley Hauerwas, who, as one student reports, dismantles Emersonian assumptions by announcing in his classroom, "I don't want you to think for yourselves. I want you to think like me" ([35], p. 26). Furthermore, as Edmundson and Wallace demonstrate, the American ideal for Protestant-inflected, democratic education has worthwhile and moral ends. Edmundson argues that American education has the potential to influence students to become "wiser, more vital, kinder, sadder, more thoughtful, more worth the admiration of their children [ ... ] because they are free to become who they aspire to be after their own peculiar fashions" ([29], p. 142). On the other hand, Gregory's argument about the Reformation questions whether liberating students, in Edmundson's words, "to become who they aspire to be after their own peculiar fashions" can possibly produce the virtuous results Edmundson lists because of the radical individualism it encourages ([29], p. 142). Alasdair MacIntyre, in After Virtue (1981), a project similar to Gregory's, suggests more directly that Edmundson's aspirations are impossible given the "grave disorder" of "the language of morality" in our culture ([36], p. 2).

Gregory's and MacIntyre's critiques of post-Reformation culture demonstrate how many educators are indeed working against cultural assumptions regarding the individual and the purpose of learning, assumptions wrought from Protestantism and self-reliance. For such teachers, both Protestant and Catholic, it may be helpful to consider seriously not only Brownson's assertion that "transcendentalism is the strict logical termination of Protestantism," but the history of transcendentalism, which is recognized as the first major literary movement in the United States ([2], p. 127). In this history, Miller states that transcendentalism itself was "no longer visible" by 1850 , concluding that "it had won its point" when "America adopted it and made it orthodox" ([8], pp. 13-14). Given how deeply Americans internalized its principles, the school of transcendentalism was, according to Miller, no longer needed. As many educators today will affirm, students tend to step into our classrooms with "Trust thyself" at their fingertips and with internal barriers fully constructed against docility ([19], p. 30). If, as the nation's writers have suggested, transcendentalism is the progression and outgrowth of the Reformation, educators should consider the possibility that Protestantism is indeed most alive in self-reliance. Emersonian perspectives on teaching, learning, and the individual are therefore religious issues educators must engage as such in order to communicate with their students about the moral traditions to which they may be indocile.

Conflicts of Interest: The author declares no conflict of interest.

\section{References}

1. Edmund Burke. Burke's Politics: Selected Writings and Speeches of Edmund Burke on Reform, Revolution, and War. Edited by Ross J. S. Hoffman and Paul Levack. New York: Alfred A. Knopf, 1949.

2. Orestes Brownson. The Works of Orestes A. Brownson. Edited by Henry F. Brownson. Detroit: Thorndike Nourse Publisher, 1884, vol. VI. 
3. Ralph Waldo Emerson. The Complete Works of Ralph Waldo Emerson. Boston: Houghton Mifflin Co., 1883, vol. X.

4. Brad S. Gregory. The Unintended Reformation: How a Religious Revolution Secularized Society. Cambridge: Belknap Press, 2012.

5. Walter Channing. "Reflections on the Literary Delinquency of America." North American Review 2 (1815): 33-43.

6. Sydney Smith. "Statistical Annals of the United States of America." Edinburgh Review 33 (1820): 69-80.

7. Francis Otto Matthiessen. American Renaissance: Art and Expression in the Age of Emerson and Whitman. New York: Oxford University Press, 1941.

8. Perry Miller. The Transcendentalists: An Anthology. Cambridge: Harvard University Press, 1950.

9. Margaret Fuller. Margaret Fuller, Critic: Writings from the New-York Tribune 1844-1846. Edited by Judith Mattson Bean and Joel Myerson. New York: Columbia University Press, 2000.

10. Catharine Maria Sedgwick. The Life and Letters of Catharine M. Sedgwick. Edited by Mary E. Dewey. New York: Harper \& Brothers Publishers, 1871.

11. Catharine Maria Sedgwick. The Linwoods, or, "Sixty Years Since" in America. Edited by Maria Karafilis. Hanover: University Press of New England, 2002.

12. William Ellery Channing. Selected Writings. Edited by David Robinson. New York: Paulist Press, 1985.

13. Alexis de Tocqueville. Democracy in America. Translated by Henry Reeve. Edited by Isaac Kramnick. New York: W. W. Norton \& Company, 2007.

14. Henry David Thoreau. Reform Papers. Edited by Wendell Glick. Princeton: Princeton University Press, 1973.

15. George F. Sensabaugh. Milton in Early America. Princeton: Princeton University Press, 1964.

16. William Ellery Channing. The Works of William E. Channing. Boston: American Unitarian Association, 1901.

17. Ralph Waldo Emerson. The Conduct of Life and Natural History of Intellect and Other Papers. Boston: Houghton Mifflin Company, 1929.

18. Stanley Fish. Surprised by Sin: The Reader in Paradise Lost, 2nd ed. Cambridge: Harvard University Press, 1997.

19. Ralph Waldo Emerson. Essays: First and Second Series. New York: Library of America, 1991.

20. Joe B. Fulton. "Reason for a Renaissance: The Rhetoric of Reformation and Rebirth in the Age of Transcendentalism." The New England Quarterly 80 (2007): 383-407. [CrossRef]

21. William Dean Howells. The Rise of Silas Lapham. New York: W. W. Norton \& Company, 1982.

22. Mark Twain. What is Man? and Other Philosophical Writings. Edited by Paul Baender. Berkeley: University of California Press, 1973.

23. David S. Reynolds. Beneath the American Renaissance: The Subversive Imagination in the Age of Emerson and Melville. New York: Oxford University Press, 1988.

24. Candy Gunther Brown. The Word in the World: Evangelical Writing, Publishing, and Reading in America, 1789-1880. Chapel Hill: University of North Carolina Press, 2004.

25. Anne C. Rose. Transcendentalism as a Social Movement, 1830-1850. New Haven: Yale University Press, 1981.

26. Richard C. Pettigrew. "Emerson and Milton." American Literature 3 (1930): 45-59. [CrossRef]

27. Mark A. Noll. The Civil War as a Theological Crisis. Chapel Hill: University of North Carolina Press, 2006.

28. Harriet Beecher Stowe. Uncle Tom's Cabin, or, Life Among the Lowly. Edited by Ann Douglas. New York: Penguin Books, 1981.

29. Mark Edmundson. Why Read? New York: Bloomsbury, 2004.

30. David Foster Wallace. This is Water: Some Thoughts, Delivered on a Significant Occasion, about Living a Compassionate Life. New York: Little, Brown and Co., 2009.

31. Henry David Thoreau. Walden, Civil Disobedience, and Other Writings. Edited by William Rossi. New York: W.W. Norton \& Company, 2008.

32. Russell Ronald Reno. Fighting the Noonday Devil and Other Essays Personal and Theological. Grand Rapids: William B. Eerdmans Publishing Company, 2011.

33. Carl F. Krummel. "Catholicism, Americanism, Democracy, and Orestes Brownson." American Quarterly 6 (1954): 19-31.

34. Richard Warrington Baldwin Lewis. The American Adam: Innocence, Tragedy, and Tradition in the Nineteenth Century. Chicago: University of Chicago Press, 1955. 
35. William Cavanaugh. "Stan the Man: A Thoroughly Biased Account of a Completely Unobjective Person." In The Hauerwas Reader. Edited by John Berkman and Michael Cartwright. Durham: Duke University Press, 2001, pp. 17-32.

36. Alasdair MacIntyre. After Virtue: A Study in Moral Theory, 3rd ed. Notre Dame: University of Notre Dame Press, 2007. 